\title{
ANALISIS FAKTOR YANG MEMENGARUHI FREKUENSI KUNJUNGAN BALITA KE POSYANDU
}

\author{
Evi Khrisna, Siti Aisyah Hamid, Rizki Amalia \\ Universitas Kader Bangsa Palembang, Jl.H.M Mayjend Ryacudu No.88, 082371974905 \\ Email: ramdhanilist@gmail.com
}

\begin{abstract}
ABSTRAK
Posyandu di Indonesia berfungsi sebagai salah satu media promosi dan sarana pemantauan pertumbuhan bayi balita, kegiatan posyandu ini sangat diharapkan dapat mendeteksi kasus gizi buruk secara dini di masyarakat sehingga tidak berkembang menjadi angka kejadian luar biasa. Penelitian bertujuan ingin mengetahui hubungan pendidikan ibu, pekerjaan ibu dan jarak ke posyandu dengan frekuensi kunjungan balita ke posyandu. Metode pada penelitian ini menggunakan cross sectional dengan jumlah populasi 1.487 dan sampel sebanyak 94 responden. Analisa data menggunakan uji statistik chi square dengan $p$ value $\leq$ nilai $\alpha(0,05)$. Hasil penelitian ini dari 39 responden yang berpendidikan rendah dengan frekuensi kunjungan balita ke posyandu rendah sebanyak $30(76,9 \%)$ dengan p value $=0,005$, dari 60 responden yang tidak bekerja dengan frekuensi kunjungan balita ke posyandu tinggi sebanyak 31 responden $(51,7 \%) p$ value $=0,01$, dari 61 responden jarak posyandu dekat dengan frekuensi kunjungan balita ke posyandu tinggi sebanyak 33 responden $(54,1 \%)$ p value = 0,002 . Ada hubungan yang bermakna pendidikan ibu, pekerjaan ibu dan jarak ke posyandu dengan frekuensi kunjungan balita ke posyandu
\end{abstract}

Kata kunci: frekuensi kunjungan balita; pendidikan; pekerjaan; jarak ke posyandu

\section{THE ANALYSIS OF INFLUENCING FACTORS OF TOODLERS'S VISITS TO INTEGRATED HEALTHCARE CENTER}

\begin{abstract}
Integrated Healthcare Center in Indonesia has functions as promotion and monitoring the growth of toddlers under five. It is hoped that the activity of Integrated Healthcare Center can detect cases of malnutrition early in the community so that it does not develop into an extraordinary number of incidents. This study was aimed to determine the relationship between mother's education level, occupation and distance to Health Centre with the frequency of visits by toddlers to Integrated Healthcare Center. The method in this study used cross sectional with a population of 1,487 and a sample of 94 respondents. Data analysis used Chi Square statistical test with $p$ value $\leq \alpha$ value $(0.05)$. The results of this study shows 39 respondents with low education has low frequency of toddler visits to Integrated Healthcare Center as many as 30 (76.9\%) with $p$ value $=0.005,60$ respondents who did not work with has high frequency of toddler visits to Integrated Healthcare Center as many as 31 respondents (51.7\%) p value $=0.01$, and 61 respondents who live closely to Integrated Healthcare Center has high toddlers' visits to Integrated Healthcare Center as many as 33 respondents (54.1\%) $p$ value $=0.002$.
\end{abstract}

Keywords: frequency of toddler visits; mother's education; occupation; distance to Integrated Healthcare Center

Jurnal SMART Kebidanan licensed under a Creative Commons Attribution-ShareAlike 4.0 International License. 


\section{LATAR BELAKANG}

Hasil Riset Kesehatan Dasar (Riskesdas) Kementerian Kesehatan 2018 menunjukkan angka 17,7 persen bayi yang usia di bawah 5 tahun (balita) masih mengalami masalah gizi. Dimana, angka tersebut terdiri dari balita yang mengalami gizi buruk sebesar 3,9 persen dan yang menderita gizi kurang sebesar 13,8 persen. Sebagai informasi, dalam 1.000 hari pertama (sejak janin dalam kandungan hingga berusia dua tahun) kehidupan bayi merupakan usia emas bagi tumbuh kembang anak. Sayangnya anak-anak yang seharusnya menjadi harapan masa depan bangsa Indonesia masih banyak yang mengalami masalah gizi $(29,9 \%)$ di usia dini.

Dari data penimbangan yang dicatat di KMS dapat diketahui bahwa status pertumbuhan balita, apabila penyelenggaraan Posyandu baik maka upaya untuk pemenuhan dasar pertumbuhan anak akan baik pula. Cakupan kunjungan balita ke Posyandu yaitu jumlah balita yang ditimbang (D) dibagi dengan jumlah balita yang ada (S) di wilayah kerja Posyandu dikali 100 posyandu, hasilnya minimal harus mencapai 80 persen (Kemenkes RI, 2016).

Menurut Departemen Kesehatan RI, menyatakan bahwa pencapaian balita yang datang dan ditimbang di Posyandu dibanding dengan seluruh balita (D/S) dalam kegiatan Posyandu di Indonesia tahun 2017 adalah sebesar 71,4 posyandu dari target 80 persen pada tahun 2017, dan provinsi Sumatera Selatan capaian D/S adalah sebesar 84 persen (Kemenkes RI, 2018).

Berdasarkan data yang diperoleh dari Dinas Kesehatan Kabupaten Ogan Komering Ulu tahun 2018 bahwa cakupan balita yang ditimbang sebanyak 14.658 orang (68,5 persen) dari 43.091 balita masih rendahnya persentase cakupan penimbangan balita dari target pencapaian 80 persen. Sedangkan, pada tahun 2019 adanya penurunan dalam persentase cakupan penimbangan balita (D/S) yaitu 65,4 persen dari 43.779 balita. Bahwa partisipasi ibu untuk menimbang balitanya ke posyandu di 13 Kecamatan, 18 Puskesmas Kota Baturaja Kabupaten Ogan komering Ulu Tahun 2019 selama 1 tahun masih rendah. (Dinkes Kab.OKU, 2019).
Jumlah Posyandu di wilayah kerja UPTD Puskesmas Sukaraya mempunyai 16 Posyandu yang terbagi di satu desa dan dua kelurahan diantaranya Posyandu Damai Sejartera, Posyandu Lestari, Posyandu Anggrek, Posyandu Durian, Posyandu Melati, Posyandu Mawar, Posyandu Bungur, Posyandu Asoka, Posyandu Edelweis, Posyandu Melati, Posyandu Ganesha, Posyandu Asyifa, Posyandu Rambutan, Posyandu Mawar 1, Posyandu Melati, Posyandu Mawar 2 (Puskesmas Sukaraya, 2019).

Berdasarkan studi pendahuluan yang dilakukan oleh peneliti di UPTD Puskesmas Sukaraya Kabupaten Ogan Komering Ulu indikator yang digunakan dalam pengukuran pelaksanaan posyandu ini antara lain frekuensi kunjungan (penimbangan) setiap bulan, namun tidak semua ibu balita berkunjung ke posyandu setiap bulan sehingga frekuensinya kurang dari 12 kali setahun. Adapun, dengan pencapaian pada tahun 2018 balita (D/S) sebesar 64,61 persen dari target sebesar 70 persen, menunjukkan belum bisa memenuhi capaian sebesar 5,39 persen dari target tersebut. Pada tahun 2019 balita D/S sebesar 66,36 persen dari target 75 persen, menunjukkan belum bisa memenuhi capaian sebesar 8,64 persen dari target. Hal ini berarti target sasaran tahun 2018 dan 2019 terjadi peningkatan yang tidak dapat dikejar oleh kunjungan balita (D/S) di Posyandu dalam wilayah kerja Puskesmas Sukaraya (Puskesmas Sukaraya, 2019).

Salah satu upaya dalam mengurangi angka kesakitan dan kematian balita adalah dengan melakukan pemeliharaan kesehatannya. Pemeliharaan kesehatan anak balita dititikberatkan kepada upaya pencegahan dan peningkatan kesehatan serta pengobatan dan rehabilitasi yang dapat dilakukan di Puskesmas, Puskesmas Pembantu, Polindes dan di Posyandu (Nain, 2018).

Upaya pengembangan kualitas sumber daya manusia yang mengoptimalkan potensi tumbuh kembang anak dapat dilaksanakan secara merata apabila sistem pelayanan kesehatan yang berbasis masyarakat seperti posyandu dapat dilakukan secara efektif dan efisien, serta dapat menjangkau semua sasaran yang membutuhkan pelayanan salah satunya adalah 
layanan tumbuh kembang anak (Kemenkes RI, 2015).

Posyandu di Indonesia merupakan salah satu bentuk upaya kesehatan yang strategis serta berfungsi sebagai media promosi maupun sarana pemantauan pertumbuhan bayi dan balita, kegiatan posyandu diharapkan dapat mendeteksi kasus gizi buruk secara dini di masyarakat sehingga tidak berkembang menjadi kejadian luar biasa. Angka balita yang ditimbang dalam posyandu dapat menjadi indikator keaktifan masyarakat dalam ikut serta posyandu. Maka keaktifan ibu dalam menimbang bayi di Posyandu menjadi salah satu perhatian utama pemerintah, karena agar dapat memantau tumbuh dan kembang balita (Kemenkes RI, 2017).

Penimbangan balita dilakukan tiap bulan di Posyandu untuk pemantauan pertumbuhan dan mendeteksi sedini mungkin penyimpangan pertumbuhan balita (Dinas Kesehatan RI. 2016). Perilaku ibu mengunjungi posyandu membawa anak balitanya, akan dipermudah jika ibu tahu apa manfaat membawa anak ke posyandu. Karakteristik ibu yang merupakan bagian dari karakteristik individu seseorang mempunyai peranan penting terhadap pertumbuhan balita. Faktor-faktor yang berhubungan dengan cakupan penimbangan balita (D/S) ke posyandu adalah pendidikan ibu, pekerjaan ibu, pengetahuan ibu, jarak ke posyandu, motivasi ibu, dukungan keluarga dan tokoh masyarakat (A.H Angkat, 2015).

\section{METODE}

Desain penelitian ini adalah kuantitatif dengan menggunakan metode survei analitik melalui pendekatan cross sectional. Penelitian telah dilaksanakan pada bulan Maret-Agustus 2020 di UPTD Puskesmas Sukaraya Kabupaten Ogan Komering Ulu Sumatera Selatan. Populasi pada penelitian ini semua ibu yang membawa balitanya ke Posyandu di wilayah kerja UPTD Puskesmas Sukaraya berjumlah 1.487 responden. Sampel pada penelitian ini sebanyak 94 responden menggunakan sistematis random sampling (Notoatmodjo , 2017).
Metode Pengumpulan data menggunakan data sekunder yang diperoleh dari Medical record atau Buku induk posyandu, KM dan KK. Alat ukur pengumpulan data dapat dilakukan menggunakan check list yang sesuai dengan variabel yang diteliti. Analisis data menggunakan analisis univariat untuk memperoleh gambaran distribusi frekuensi dan persentase dan analisis bivariat untuk mengetahui hubungan antara variabel pendidikan ibu, pekerjaan ibu dan jarak ke posyandu dengan frekuensi kunjungan balita ke posyandu menggunakan uji statistic chi square dimana batas kemaknaan adalah 0,05.

\section{HASIL}

Analisis univariat digunakan untuk melihat gambaran distribusi frekuensi variabel independen meliputi : pendidikan ibu, pekerjaan ibu, jarak ke posyandu dan frekuensi kunjungan balita ke posyandu (Tabel 1).

\section{Tabel 1 Karakteristik Responden ( $n=94)$}

\begin{tabular}{|c|c|c|}
\hline Varibel Independen & $\mathrm{n}$ & $\begin{array}{c}\text { Persentase } \\
(\%)\end{array}$ \\
\hline \multicolumn{3}{|l|}{ Pendidikan Ibu } \\
\hline Rendah & 39 & 41,5 \\
\hline Tinggi & 55 & 58,5 \\
\hline \multicolumn{3}{|l|}{ Pekerjaan Ibu } \\
\hline Tidak Bekerja & 60 & 63,8 \\
\hline Bekerja & 34 & 36,2 \\
\hline \multicolumn{3}{|l|}{ Jarak ke Posyandu } \\
\hline Jauh & 33 & 35,1 \\
\hline Dekat & 61 & 64,9 \\
\hline \multicolumn{3}{|l|}{ Frekuensi Kunjungan } \\
\hline Rendah & 55 & 58,5 \\
\hline Tinggi & 39 & 41,5 \\
\hline
\end{tabular}

Tabel 1 diketahui bahwa terdapat 55 responden $(58,5 \%)$ berada dalam pendidikan tinggi, 60 responden $(63,8 \%)$ tidak bekerja dan 61 responden $(64,9 \%)$ jarak ke posyandu jauh. kunjungan balita ke posyandu rendah sebanyak 55 responden $(58,5 \%)$ dan frekuensi kunjungan balita ke posyandu tinggi sebanyak 39 responden (41,5\%).

Analisis bivariat dilakukan untuk mengetahui hubungan pendidikan ibu, pekerjaan ibu dan jarak ke posyandu dengan frekuensi kunjungan 
balita ke posyandu di Wilayah Kerja UPTD Puskesmas Sukaraya Kabupaten Ogan Komering Ulu (Tabel 2).

Tabel 2 Hubungan Pendidikan Ibu, Pekerjaan lbu dan Jarak ke Posyandu dengan Frekuensi Kunjungan Balita ke Posyandu $(n=94)$

\begin{tabular}{|c|c|c|c|c|c|c|c|}
\hline \multirow[t]{3}{*}{ Varibel } & \multicolumn{4}{|c|}{$\begin{array}{c}\text { Frekuensi } \\
\text { kunjungan ke } \\
\text { Posyandu }\end{array}$} & \multirow{2}{*}{\multicolumn{2}{|c|}{ Jumlah }} & \multirow[t]{3}{*}{$p$} \\
\hline & \multicolumn{2}{|c|}{ Rendah } & \multicolumn{2}{|c|}{ Tinggi } & & & \\
\hline & $n$ & $\%$ & $n$ & $\%$ & $n$ & $\%$ & \\
\hline $\begin{array}{l}\text { Pendidika } \\
\mathrm{n} \text { lbu }\end{array}$ & & & & & & & \\
\hline Rendah & 30 & 76,9 & 9 & 23,1 & 39 & 100 & 0,005 \\
\hline Tinggi & 25 & 45,5 & 30 & 54,5 & 55 & 100 & \\
\hline $\begin{array}{l}\text { Pekerjaan } \\
\text { lbu }\end{array}$ & & & & & & & 0,01 \\
\hline $\begin{array}{l}\text { Tidak } \\
\text { bekerja }\end{array}$ & 29 & 48,3 & 31 & 51,7 & 60 & 100 & \\
\hline Bekerja & 26 & 76,5 & 8 & 23,5 & 34 & 100 & \\
\hline $\begin{array}{l}\text { Jarak } \\
\text { Posyandu }\end{array}$ & & & & & & & \\
\hline Jauh & 27 & 81,8 & 6 & 18,2 & 33 & 100 & 0,002 \\
\hline Dekat & 28 & 45,9 & 33 & 54,1 & 61 & 100 & \\
\hline
\end{tabular}

Tabel 2 menunjukkan frekuensi Analisis bivariat digunakan untuk mengetahui pengaruh variabel independen (pendidikan ibu, pekerjaan ibu dan jarak ke posyandu) dengan variabel dependen (frekuensi kunjungan balita ke posyandu). dari 39 responden yang berpendidikan rendah dengan frekuensi kunjungan balita ke posyandu rendah sebanyak $30(76,9 \%)$ dengan $p$ value $=0,005$, dari 60 responden yang tidak bekerja dengan frekuensi kunjungan balita ke posyandu tinggi sebanyak 31 responden $(51,7 \%) p$ value $=0,01$ dan dari 61 responden jarak posyandu dekat dengan frekuensi kunjungan balita ke posyandu tinggi sebanyak 33 responden $(54,1 \%)$ p value = 0,002 .

\section{PEMBAHASAN}

Hasil penelitian menunjukkan sebagian besar responden yang berpendidikan rendah dengan frekuensi kunjungan balita ke posyandu rendah sebanyak 30 orang (76,9 persen). Pendidikan yang dijalani seseorang memiliki pengaruh pada peningkatan kemampuan berfikirnya, dengan kata lain orang yang berpendidikan lebih tinggi akan mengambil keputusan yang lebih rasional, umumnya terbuka untuk menerima hal baru dibandingkan dengan individu yang berpendidikan lebih rendah (Kemenkes RI, 2016).

Hasil dari status pekerjaan ibu dengan frekuensi kunjungan balita didapatkan hasil dari 60 responden (63,8 persen) yang tidak bekerja. Status pekerjaan ibu balita memiliki hubungan dengan frekuensi penimbangan balita ke posyandu. Ibu balita yang bekerja maupun tidak bekerja memiliki peluang sama untuk berkunjung dan menimbang balitanya ke posyandu. Berdasarkan hasil wawancara dengan ibu yang memiliki balita rata-rata alasan ibu adalah bekerja untuk menutupi perekonomian karena pendapatan suami yang dianggap kurang untuk memenuhi kebutuhan sehari-hari. Ibu balita yang bekerja namun memiliki frekuensi penimbangan balita cukup dapat dikaitkan dengan pengetahuan, sikap dan jenis pekerjaan ibu balita. Pengetahuan dan sikap ibu yang baik sehingga membuat ibu tetap membawa balitanya ke Posyandu dikarenakan ibu memiliki perhatian dan kepedulian yang besar terhadap balitanya. Selain itu jenis pekerjaan ibu juga dapat mempengaruhi keaktifan ibu membawa balitanya ke posyandu (Safitri, 2016).

Hasil penelitian menunjukkan jarak ke posyandu jauh sebanyak 61 responden $(64,9$ persen). Frekuensi kunjungan balita ke Posyandu karena jarak tempat tinggal ibu yang jauh dari lokasi Posyandu dan tidak adanya transportasi yang bisa mengantar ibu menuju lokasi menjadi alasan bagi ibu sehingga keaktifan ibu untuk membawa balitanya ke posyandu masing kurang.

Hasil penelitian ini sejalan dengan penelitian yang dilakukan oleh (Ann, 2017) di Kitui County Kenya bahwa ada hubungan pendidikan ibu dengan frekuensi kunjungan balita dengan ( $p$ value $=0,003$ ) dan menyatakan faktor pendidikan ibu balita yang baik akan mendorong ibu-ibu balita untuk membawa anaknya ke pelayanan kesehatan. Begitu pula, dengan jarak rumah ibu dengan frekuensi kunjungan balita dengan $(p$ value $=0,01)$ menyatakan faktor jarak rumah yang dekat akan mendorong ibu 
balita akan membawa anaknya ke pelayanan kesehatan (Ann, 2017).

Hasil penelitian ini sesuai yang dilakukan oleh (Jane Ilusa Nyabuti, 2015) di Nyamira didapatkan hasil bahwa ada hubungan tingkat pendidikan dengan cakupan pemantauan pertumbuhan pada anak usia 10-59 bulan dengan $p$ value $=0,003$. Hasil penelitian sejalan yang dilakukan oleh Cahya (2016) tentang Frekuensi kunjungan balita dimana analisis bivariat menunjukkan 93,8 persen ibu yang bekerja. Sedangkan ibu tidak bekerja 55,8 persen yang mampu membawa balitanya ke Posyandu pada saat hari kerja. Hasil analisis statistik pun menunjukkan adanya hubungan bermakna antara pekerjaan ibu dengan Frekuensi kunjungan balitake posyandu di Kota Solok tahun 2015 ( $p=0,026$ ) (Cahya, 2016).

Penelitian ini sejalan dengan hasil penelitian Asthi dan Anjarwati (2017) dengan sampel 168 orang dimana hasil analisis menunjukkan bahwa ibu balita dengan status bekerja memiliki frekuensi penimbangan balita yang cukup sebesar 54,8 persen, dan memiliki frekuensi penimbangan balita yang kurang sebesar 45,2 persen. Sedangkan ibu balita dengan status tidak bekerja memiliki frekuensi penimbangan balita yang cukup sebesar 76,8 persen, dan memiliki frekuensi penimbangan balita yang kurang sebesar 23,3 persen.

Hasil penelitian ini dapat disimpulkan bahwa hubungan pendidikan ibu dengan frekuensi kunjungan balita ke posyandu adalah lebih dominan pada responden yang berpendidikan rendah karena, rendahnya pendidikan ibu akan berdampak pada rendahnya pengetahuan ibu yang berpengaruh pada kesadaran dan keaktifian ibu untuk mengujungi fasilitas pelayanan kesehatan misalnya Puskesmas, polindes, poskesdes dan posyandu. Makin rendah pengetahuan dan sikap ibu, makin sedikit keinginannya untuk memanfaatkan pelayanan kesehatan termasuk berkunjung ke posyandu untuk menimbangkan balitanya sebulan sekali. Oleh sebab itu, pendidikan ibu adalah faktor yang cukup berpengaruh terhadap pemenuhan frekuensi kunjungan balita ke posyandu. jumlah frekuensi kunjungan balita ke posyandu yang memiliki jenis pekerjaan sebagai petani/nelayan/buruh yang dimana pekerjaan ibu tersebut dapat diatur sendiri waktu bekerjanya sesuai keinginan ibu memiliki frekuensi penimbangan balita cukup dan pada saat hari penimbangan ibu dapat menunda aktivitas pekerjaannya untuk membawa balitanya ke posyandu dan dapat kembali bekerja setelah dari posyandu. Ibu balita yang tidak bekerja namun memiliki frekuensi penimbangan balita kurang dapat di sebabkan oleh jarak tempat tinggal dan akses transportasi. Frekuensi kunjungan balita ke Posyandu karena jarak tempat tinggal ibu yang jauh dari lokasi Posyandu dan tidak adanya transportasi yang mengantar ibu menuju lokasi posyandu menjadi alasan bagi ibu sehingga kurang membawa balitanya ke posyandu.

\section{KESIMPULAN DAN SARAN}

Hasil penelitian ini menunjukkan adanya hubungan yang bermakna pendidikan ibu, pekerjaan ibu dan jarak ke posyandu dengan frekuensi kunjungan balita ke posyandu terbukti secara statistik di wilayah kerja UPTD Puskesmas Sukaraya Kabupaten Ogan Komering Ulu Tahun 2019. Bidan diharapkan meningkatkan pengetahuan kepada ibu balita tentang manfaat kunjungan balitanya ke posyandu untuk optimalisasi tumbuh kembang balita.

\section{REFERENSI}

Angkat, A. H. (2015) Faktor-Faktor Yang Berhubungan Dengan Partisipasi Ibu Balita Untuk Menimbangkan Anaknya Ke Posyandu Di Desa Penanggalan Kecamatan Penanggalan Kota Subulussalam.

Adriani, M. \& Wirjatmadi, B. (2018). Pengantar Gizi Masyarakat. Jakarta: Prenada Media. Brown, J.E. Nutrition through the life cycle; fourth edition. Belmont: Thomson wadswoth

Amalia, R., \& Larasati, E. M. L. M. L. (2018). Mobilisasi Dini Dan Personal Hygiene Dengan Lamanya Penyembuhan Luka Perineum Padaibu Nifas. Masker Medika, 6(2), 480-485.

Amalia, R., \& Sari, D. A. (2020). Hubungan Kehamilan Postterm, Partus Lama Dan Air Ketuban Bercampur Mekonium Dengan Kejadian Asfiksia Neonatorum. Jurnal Kesehatan dan Pembangunan, 10(19), 32-37.

Ann, K. (2017). Factors Influencing Community Participation In Maternal Health Care Project In Kitui County A Research Project Report 
Submitted In Partial Fulfillment of The Requirement For The Award Of Master Of Arts Degree In Project Planning And Management At The University Of Nairobi.

Cahya, E., Harnida, H., \& Indrianita, V. (2019). Hubungan Dukungan Sosial Dengan Kualitas Hidup Lansia Di Posyandu Lansia Wiguna Karya Kebonsari Surabaya. NERSMID: Jurnal Keperawatan Dan Kebidanan, 2(1), 33-47.Dinas Kesehatan Ogan Komering Ulu. (2018). Profil Kesehatan Kabupaten Ogan Komering Ulu

Hasan, A. G., \& Adisasmito, W. B. (2017). Analisis Kebijakan Pemanfaatan Dana Kapitasi JKN pada FKTP Puskesmas di Kabupaten Bogor Tahun 2016. Jurnal Kebijakan Kesehatan Indonesia: JKKI, 6(3), 127-137.

Nain, U. (2015). Posyandu: upaya kesehatan berbasis masyarakat.

Notoadmodjo. S.(2017). Promosi Kesehatan Teori Dan Aplikasi. Jakarta.

Nursalam, A., \& Supriyani, T. (2017). Gambaran Sikap Dan Kemudahan Ibu Balita Ke Posyandu Di Desa Singasari Kecamatan Singaparna Kabupaten Tasikmalaya Tahun 2015. Jurnal Kesehatan Bidkesmas Respati, 1(08), 35-41.

Novitasari, D., \& Amalia, R. (2020). Hubungan Kpd, Janin Besar Dan Inersia Uteri Dengan Kejadian Kala II. Jurnal Kesehatan dan Pembangunan, 10(19), 8-17.

Nyabuti, J. I. (2015). Factors associated with the continuation of growth monitoring among children
10 to 59 months old in Nyamira County, Kenya. Unpublished Masters dissertation, Kenyatta University, Nairobi, Kenya.

Maryanti. (2015). Buku Ajar Neonatus, Bayi \& Balita. Prenada Media Group: Jakarta

Muriithi, A. K. (2017). Factors Influencing Community Participation in Maternal Health Care Project in Kitui County Kenya (Doctoral dissertation, University of Nairobi).

Sari, D. S., \& Amalia, R. (2020). Hubungan Lama Menstruasi Dan Status Gizi Dengan Kejadian Anemia Pada Remaja Putri. Jurnal Kesehatan dan Pembangunan, 10(19), 18-23.

Septiari, B. B. (2012). Mencetak Balita Cerdas dan Pola Asuh Orang Tua. Yogyakarta. (Supartini, 2015).

Saifuddin, A.B dkk. (2015). Buku Panduan Praktis Pelayanan Kesehatan Maternal dan Neonatal. Jakarta : BP-SP (Syahlan, 2018).

Soetjiningsih, \& Ranuh, IG.N. Gde. (2017). Tumbuh Kembang Anak. Edisi II. Jakarta: EGC

Suryaputri, A., \& Anjarwati, A. (2013). Faktor-Faktor yang Berhubungan dengan Kejadian Ketuban Pecah Dini (KPD) pada Ibu Bersalin di RSUD Wates Kulon Progo Tahun 2013 (Doctoral dissertation, STIKES'Aisyiyah Yogyakarta).

Proverawati, A. \& Sumeru, A. (2018). Optimalisasi Peran Kader Posyandu Dalam Meningkatkan Kemandirian Gizi Dan Kesehatan Untuk Mencegah Hipertensi Pada Lansia Di Desa Susukan Kecamatan Sumbang Kabupaten Banyumas. Jurnal IImiah Medsains, 4(1),40-45. 